\title{
Oportunistik Incumbent dalam Penganggaran Pendapatan dan Belanja pada Pemilihan Kepala Daerah Serentak Tahun 2017
}

\author{
Dodik Ariyanto ${ }^{1}$ \\ Ayu Aryista Dewi ${ }^{2}$ \\ ${ }^{1,2}$ Fakultas Ekonomi dan Bisnis, Universitas Udayana, Indonesia \\ email: dodikariyanto@unud.ac.id
}

DOI: https://doi.org/10.24843/JIAB.2019.v14.i01.p05

\section{Jurnal Ilmiah Akuntansi dan Bisnis (JIAB) \\ https://ojs.unud.ac.id/index.php/jiab/ user/profile}

Volume 14

Nomor 1

Januari 2019

Halaman 41-55

p-ISSN 2302-514X

e-ISSN 2303-1018

\section{INFORMASI ARTIKEL}

Tanggal masuk: 18 Oktober 2018

Tanggal revisi: 15 Nopember 2018

Tanggal diterima: 01 Januari 2019

\begin{abstract}
ABSTRAK
Penelitian bertujuan mengkaji pengaruh perilaku oportunistik incumbent menyusun anggaran terkait pemilihan umum kepala daerah (pemilukada) serentak kabupaten, kota dan provinsi di Indonesia tahun 2017. Penelitian juga menguji perbedaan perilaku oportunistik incumbent saat menyusun anggaran bagi kepala daerah incumbent terpilih dibandingkan kepala daerah tidak terpilih, serta perbedaan perilaku oportunistik incumbent setahun sebelum dan saat dilaksanakan pemilukada serentak. Populasi penelitian adalah seluruh kabupaten, kota, dan provinsi di Indonesia peserta pemilukada tahun 2017. Metode penyamplingan menggunakan purposive sampling. Data dianalisis menggunakan regresi liner berganda dan uji beda t-Test. Hasil analisis menunjukan Pendapatan Asli Daerah (PAD) dan Sisa Lebih Pembiayaan Anggaran (SiLPA) berpengaruh pada perilaku oportunistik incumbent dan Dana Alokasi Umum (DAU) tidak berpengaruh pada perilaku oportunistik incumbent. Hasil uji beda $t$-Test menunjukan terdapat perbedaan perilaku oportunistik incumbent pemenang dan kalah saat pemilukada serentak. Terdapat perbedaan perilaku oportunistik incumbent dalam menyususn anggaran setahun sebelum dan saat pelaksanaan pemilukada serentak tahun 2017.
\end{abstract}

Kata kunci: Oportunistik incumbent, pemilukada, anggaran pendapatan dan belanja daerah.

\section{Opportunistic Incumbent in Budgeting of Revenues and Expenditures in Simultaneous Regional Head Elections in 2017}

\section{ABSTRACT}

This study aims to examine the effects of incumbent opportunistic behavior on budget compilation related to the simultaneous election of regional heads (pemilukada) in regencies, cities, and provinces in Indonesia in 2017. In addition, the study also examines differences in incumbent opportunistic behavior when preparing budgets for elected incumbent heads compared with those who did not get elected as well as differences in incumbent opportunistic behavior a year prior to and during the simultaneous elections. The research population comprises all regencies, cities, and provinces in Indonesia. The sampling method used for this study was purposive sampling. Data were analyzed using multiple linear regression and different types of tTests. The results of the analysis showed that PAD and SiLPA had an effect on the incumbent opportunism behavior and DAK had no effect on incumbent opportunism behavior. The results of different $t$-Tests revealed differences in incumbent opportunistic behaviors of winners and losers as well as differences in incumbent opportunistic behavior in the budgeting year prior to and during the post-conflict simultaneous local elections held in 2017.

Keywords: Incumbent opportunistic behavior, elections of regional heads, regional income and expenditure budget. 


\section{PENDAHULUAN}

Anggaran Pendapatan dan Belanja Negara (APBN) dan Anggaran Pendapan dan Belanja Daerah (APBD) merupakan dokumen formal hasil kesepakatan antara eksekutif dan legislatif tentang belanja yang ditetapkan untuk melaksanakan kegiatan pemerintah dan pendapatan yang diharapkan untuk menutup keperluan belanja tersebut atau pembiayaan yang diperlukan bila terjadi defisit (PP 71, 2010). Dalam lingkungan keuangan negara, pemerintah (eksekutif) berhak menyusun anggaran dan menyampaikannya kepada pihak Dewan Perwakilan Rakyat (DPR) atau Dewan Perwakilan Rakyat Daerah (DPRD) untuk mendapatkan persetujuan sebagai pihak legislatif. Setelah mendapat persetujuan dari legislatif, pemerintah melaksanakannya dalam batas-batas apropriasi dan ketentuan peraturan perundang-undangan yang berhubungan dengan apropriasi tersebut. Selain itu, pemerintah bertanggung jawab atas penyelenggaraan keuangan kepada DPR/DPRD. Von Hagen (2002) menyatakan bahwa penganggaran di sektor publik merupakan suatu bargaining process antara eksekutif dan legislatif untuk mencapai tujuan utama pemerintahan suatu negara.

Pemerintah mempunyai tujuan utama meningkatkan kesejahteraan rakyat. Kesejahteraan bisa terwujud jika pemerintah berupaya mewujudkan keseimbangan fiskal dengan mempertahankan kemampuan keuangan negara yang bersumber dari pendapatan pajak dan sumber-sumber lainnya guna memenuhi kebutuhan masyarakat dalam bentuk belanja negara atau daerah dalam penganggaran di APBN dan APBD. Salah satu ciri penting dalam mewujudkan keseimbangan adalah berlangsungnya proses politik untuk menyelaraskan alokasi dari berbagai kepentingan masyarakat melaui APBN dan APBD (PSAP No.1). Penganggaran menurut Von Hagen (2002) terbagi ke dalam empat tahapan, yaitu executive planning, legislative approval, executive implementation, dan ex post accountability. Pencermatan terhadap alokasi belanja dalam APBN dan APBD melalui empat tahapan (Von Hagen, 2002) merupakan hal yang menarik karena terkait faktor ketaatan terhadap peraturan perundang-undangan dan proses alokasi anggaran harus berdasarkan prioritas kepentingan masyarakat. Salah satu kepentingan masyarakat yang mendapat perhatian adalah pemilihan kepala daerah (pemilukada) serentak sebagai perwujudan demokrasi di Indonesia.
Pemilukada serentak tahap pertama di tahun 2015, tahap ke-2 tahun 2017 dan tahap ke-3 tahun 2018. Tujuan pemilukada serentak adalah mengakomodir keinginan masyarakat tentang pelaksanaan pemilihan umum (pemilu) atau pemilihan umum kepala daerah yang efisien, hemat, dan efektif dari sisi pendanaan dan pelaksanaannya (UndangUndang Republik Indonesia Nomor 1 Tahun 2015 Penetapan Peraturan Pemerintah Pengganti UndangUndang Nomor 1 Tahun 2014 Tentang Pemilihan Gubernur, Bupati, dan Walikota Menjadi UndangUndang).

Efektivitas dan efisiensi penyelenggaraan pemilu atau pemilukada serentak belum pernah dievaluasi secara serius oleh pemerintah maupun DPR. Pemilukada langsung dan serentak di beberapa daerah Indonesia memberikan beban keuangan sangat besar bagi daerah dan pemerintah pusat (http:/ /presidenri.go.id/program-prioritas-2/pilkadaserentak) 19 Mei 2015. Hal ini hanya dilihat dari beban atau pos anggaran pemilukada yang ditanggung oleh pemerintah secara nyata dikeluarkan dari Anggaran Pendapatan Belanja Daerah (APBD) dan Anggaran Pendapatan dan Belanja Negara (APBN), disamping pemafaatan pos lain dalam anggaran yang tidak sesuai peruntukannnya untuk kepentingan pemilukada (https://republika.co.id) 24 Januari 2015. Ritonga \& Alam (2010) menjelaskan sebagai calon kepala daerah, incumbent memiliki peluang besar dalam memanfaatkan pos-pos belanja pada APBD untuk kepentingan politiknya terutama terkait mempertahankan tapuk kepala daerah saat pemilukada.

Data pemilukada serentak bulan Februari 2017, menunjukan 60 persen incumbent atau petahana unggul. Sebanyak tiga puluh tujuh dari enam puluh satu nama incumbent atau petahana yang ikut kontestasi berpotensi melanjutkan masa baktinya lima tahun mendatang (Jawa Pos; 27 Februari 2017). Ban, Llaudet, \& Snyder (2016) menjelaskan bahwa penyebab incumbent unggul karena kualitas incumbent yang baik, kualitas penantang yang kurang baik isbanding dengan incumbent dan tersedianya dana untuk pemenangan pemilukada.

Hal menarik dari data pemilukada 2017 adalah masih ada 40 persen incumbent atau petahana mengalami kekalahan dalam pemilukada walaupun mereka mendapatkan akses politik dan dana yang luas (Jawa Pos; 27 Februari 2017). Hal ini dapat digunakan sebagai penanda demokrasi di Indonesia semakin dewasa dan berkembang. Penyebab 
incumbent atau petahana tidak bisa mempertahankan kepemimpinannya karena kasus korupsi, biaya demokrasi tinggi dan tidak seimbangnya gaji kepala daerah, serta persaingan pemilukada yang ketat Klašnja (2015).

Kekalahan petahana di Indonesia membuktikan bahwa masyarakat mulai mengevaluasi kinerja incumbent atau petahana selama menjabat. Ketika petahana tidak terpilih lagi menunjukan bahwa kinerja mereka tidak baik dan masyarakat tidak puas dengan capaiannya. Kedewasaan berpolitik rakyat mulai ditunjukan dengan memberikan hukuman atas kinerja incumbent. Kinerja incumbent atau petahana bisa dilihat dari realisasi kampanye politik dalam pos-pos belanja APBD yang terkait dengan kesejahteraan masyarakat.

Pos-pos belanja APBD yang seharusnya terkait dengan kesejahteraan masyarakat yang bisa dimanfaatkan untuk kepentingan pemilukada adalah belanja hibah dan belanja bantuan sosial. Belanja hibah dan belanja bantuan sosial merupakan komponen belanja tidak langsung yang penyalurannya tidak melalui program dan kegiatan. Belanja-belanja ini bersifat tidak mengikat dan tidak secara terus menerus, seperti bantuan kepada organisasi atau kelompok masyarakat (Permendagri 32 tahun 2011, diperbarui Permendagri 14 tahun 2016). Permendagri 32 tahun 2011 Pasal 14 menjelaskan kepala daerah diberi kuasa untuk menetapkan daftar penerima hibah beserta besaran uang atau jenis barang atau jasa yang akan dihibahkan. Belanja hibah dan belanja bantuan sosial dalam APBD di alokasikan tidak berdasarkan tolak ukur kinerja dan target kinerja, maka penentuan jumlah anggarannya cenderung "subjektif" (Ritonga \&Alam, 2010). Karena sifat kesubjektipannya maka besar atau kecilnya belanja hibah dan belanja bantuan sosial bergantung pada kekuatan kepala daerah (incumbent) dan dukungan mesin partai politiknya yang menguasai Dewan Perwakilan Rakyat Daerah (DPRD). Hasil kajian KPK menunjukkan nominal dana hibah pada APBD cenderung meningkat dalam tiga tahun terakhir. Tahun 2011 sebesar Rp15,9 triliun, tahun 2012 menjadi Rp37,9 triliun (naik 138persen) dan tahun 2013 menjadi Rp49 triliun (meningkat 29 persen)-Sub-bagian BPK Perwakilan Provinsi Kalimantan Timur (Jawa Pos; 10 Agustus 2017, 2017).

Incumbent atau petahana bersama DPR, selain dapat melakukan peningkatan alokasi anggaran pada dana hibah dan bansos, juga memungkinkan meningkatkan alokasi anggaran untuk belanja infrastruktur Abdullah \& Asmara (2006).
Peningkatan belanja pada pos belanja hibah, bansos, dan infrastruktur akan berdampak pada pos belanja lain yang dikurangi atau tidak mengalami peningkatan. Pos-pos belanja tersebut biasanya terkait belanja kebutuhan dasar, seperti pendidikan dan kesehatan yang tidak terjadi peningkatan yang signifikan atau bahkan mengalami penurunan Abdullah \& Asmara (2006); Abdullah (2012) dan Tanzi \& Davoodi (1998). Padahal jika dicermati Buletin Teknis Nomor 13 Standar Akuntansi Pemerintahan (SAP) tentang Akuntansi Hibah, telah menyatakan bahwa belanja hibah adalah belanja pemerintah dalam bentuk uang atau barang atau jasa yang dapat diberikan kepada pemerintah, organisasi internasional, pemerintah pusat atau daerah, perusahaan swata atau daerah, kelompok masyarakat, atau organisasi kemasyarakatan yang secara spesifik telah ditetapkan peruntukannya, bersifat tidak wajib dan tidak mengikat, serta tidak secara terus menerus kecuali ditentukan lain dalam peraturan perundangundangan.

Pengeluaran daerah untuk belanja maupun pengeluaran pembiayaan didanai dari pendapatan daerah. Hasil penelitian Parwati (2015); Abdullah (2012); Maryono (2013); Suartini, Ariyanto, \& Sari (2016) menjelaskan peningkatan pendapatan daerah berpengaruh pada perilaku penyusunan anggaran. Hasil penelitian yang dilakukan Abdullah (2012); Maryono (2013); Suartini et al. (2016) menunjukkan bahwa peningkatan pendapatan daerah berpengaruh terhadap perilaku oportunistik penyusun anggaran. Legislatif bekerjasama dengan eksekutif berusaha meningkatkan target pendapatan sehingga dapat meningkatkan alokasi anggaran untuk program yang mendukung kepentingan partai dan demi melanggengkan kekuasaan incumbent Suartini et al. (2016). Padahal kalau merujuk Peraturan Menteri Dalam Negeri (Permendagri) No. 13 Tahun 2006 dan Permendagri No. 64 Tahun 2013 Lampiran-2, menjelaskan pendapatan daerah bersumber dari Pendapatan Asli Daerah (PAD), dana perimbangan dan lain-lain pendapatan yang sah serta penerimaan pembiayaan lainnya.

Peningkatan pendapatan daerah akan dibarengi peningkatan pengeluaran bantuan dana hibah, dana bansos, dan pengeluaran infrastruktur. Hal ini menyebabkan pengalokasianya anggarannya lebih karena discretionary power yang dimiliki oleh kepala daerah dengan DPRD yang satu partai. Hasil penelitian Abdullah \& Asmara (2006); Abdullah (2012); Suartini et al. (2016) menunjukkan bahwa 
PAD, DAU dan SiLPA berpengaruh terhadap perilaku oportunistik penyusunan anggaran. Penelitian mengukur perilaku oportunistik penyusun anggaran, dimana peneliti memasukkan peningkatan atau perubahan belanja hibah dan bansos dari tahun sebelumnya dan tahun berjalan. Fenomena peningkatan alokasi belanja hibah dan bansos yang semakin meningkat menunjukkan perilaku oportunistik (opportunistic) penyusun anggaran.

Perilaku opportunistic dalam penelitian ini adalah memanfaatkan kesempatan yang ada, sehubungan dengan jabatan yang dipegang untuk mewujudkan kepentingannya. Seharusnya APBD ditujukan untuk sebesar-sebesar kemakmuran rakyat di daerah memang benar-benar merupakan kebutuhan masyarakat. Akan tetapi dalam prakteknya, program tersebut ditetapkan berdasarkan kepentingan masing-masing pejabat khusunya pihak eksekutif Riharjo \& Isnadi (2010). Dengan kata lain, dengan menggunakan jabatan yang dipegangnya, maka eksekutif berusaha memasukkan kepentingannya dalam penentuan anggaran. Hal inilah yang dinamakan perilaku opportunistic (memanfaatkan kesempatan).

Tanzi \& Davoodi (1998) menyatakan bahwa terdapat perilaku opportunistic politisi dalam pembuatan keputusan investasi publik seperti meningkatkan alokasi anggaran pada dana hibah, bansos, belanja infrastruktur dan belanja kebutuhan dasar seperti pendidikan dan kesehatan. Lalvani (1999) menyatakan bahwa sebelum dilaksanakan pemilu, rawan terjadi tindakan opportunistic yang dilakukan oleh kepala daerah untuk melakukan politisasi anggaran. Berbagai modus perilaku opportunistic sering terjadi seperti menetapkan alokasi anggaran yang dimodifikasi untuk memenuhi kepentingan politik dan kepentingan individu, memasukkan usulan proyek-proyek besar yang menguntungkan salah satu pihak dalam perencanaan anggaran, serta sikap cenderung lebih memperjuangkan realisasi penetapan anggaran atas proyek-proyek yang mudah dikorupsi dengan harapan mendapatkan kompensasi fee project yang cukup besar Jumaidi (2014) yang dibiayai APBD.

Sumber penerimaan APBD salah satunya adalah Pendapatan Asli Daerah (PAD) dan dana perimbangan dari pemerintah pusat. Pemerintah Pusat bertanggung jawab menjaga keseimbangan alokasi dana antar daerah. Pemerintah Pusat melakukan transfer dana ke daerah melalui beberapa mekanisme, seperti Dana Alokasi Umum (DAU),
Dana Alokasi Khusus (DAK), dan Dana Bagi Hasil $(\mathrm{DBH})$. Semua dana perimbangan tersebut disalurkan ke dalam Anggaran Pendapatan dan Belanja Daerah (APBD).

Dana Alokasi Umum (DAU) adalah sejumlah dana yang dialokasikan Pemerintah Pusat kepada setiap Daerah (Provinsi/Kabupaten/Kota) di Indonesia sebagai dana pembangunan. DAU merupakan salah satu komponen belanja pada APBN, dan menjadi salah satu komponen pendapatan pada APBD. Pemerintah Daerah memiliki kebebasan dalam memanfaatkannya tanpa campur tangan Pemerintah Pusat. Sekitar 80\% DAU yang dikelola daerah digunakan untuk belanja rutin, terutama gaji pegawai Pemerintah Daerah. DBH adalah dana yang bersumber dari penerimaan Anggaran Pendapatan dan Belanja Negara (APBN) yang dialokasikan kembali kepada daerah (penghasil) dengan pembagian sebagaimana diatur dalam Undang-undang (UU) No. 33/2004. Dana Bagi Hasil (DBH) dibagi atas DBH Pajak dan DBH Sumber Daya Alam. DBH Pajak terdiri dari pajak bumi dan bangunan (PBB), bea perolehan hak atas tanah dan bangunan (BPHTB), dan pajak penghasilan ( $\mathrm{PPh})$. Berbeda halnya dengan kedua dana perimbangan tersebut, pemerolehan dan pemanfaatan DAK harus mengikuti rambu-rambu yang telah ditetapkan oleh Pemerintah Pusat.

Riset ini memilih perilaku opportunistic eksekutif pada pemilukada serentak karena eksekutif lebih dominan dalam proses penyusunan APBD dan memiliki informasi yang lebih banyak dibanding dengan legislative (Permendagri No 13 tahun 2006 tentang Pedoman Pengelolaan Keuangan Daerah). Kondisi ini memberi peluang kepada eksekutif untuk berperilaku opportunistic. Perilaku opportunistic akan meningkat ketika ada perhelatan akbar seperti pemilukada. Keuntungan dari perilaku opportunistic digunakan sebagai dana kampanye calon kepala daerah dengan memanfaatkan belanja APBD. Jika hal ini terbukti, maka tujuan diadakan pemilukada serentak yaitu untuk efisiensi dan efektivitas anggaran tidak terwujud.

Berdasarkan uraian dan kajian riset-riset sebelumnya maka permasalahan dalam penelitian ini adalah: 1) Apakah PAD, DAU dan SiLPA berbengaruh pada oportunistik incumbent saat penyusun APBD setahun sebelum pemilukada 2017 ? 2) Apakah terjadi perbedaan oportunistik incumbent yang terpilih dan tidak terpilih kembali pada APBD setahun sebelum pemilukada 2017? 3) Apakah terjadi 
perbedaan oportunistik incumbent pada pemilukada setahun sebelum dan saat penyusunan APBD 2017 ?

Teori keagenan dapat digunakan sebagai penjelas hubungan di sektor pemerintahan, khusunya hubungan antara legislatif sebagai prinsipal dan eksekutif sebagai agen. Prinsip utama teori keagenan adalah Nexus of contract. Teori ini menyatakan hubungan kerja antara pihak yang memberi wewenang (principle) yaitu masyarakat atau rakyat dan DPRD (sebagai wakil rakyat) dengan pihak yang menerima wewenang (agensi) yaitu kepala daerah dan DPRD, dalam bentuk kontrak kerja sama. Agency theory merupakan sinergi dari teori ekonomi, teori keputusan, sosiologi, dan teori organisasi Schillemans \& Busuioc (2015). Implikasi dasar dari penerapan agency theory adalah perilaku efisiensi ataukah perilaku oportunistik bagi agen (penerima wewenang), Smith \& Bertozzi (1998).

Implikasi penerapan teori keagenan dapat menimbulkan hal positif dalam bentuk efisiensi, tetapi juga dapat menimbulkan hal negative dalam bentuk perilaku opotunistik karena adanya asimetri informasi. Smith \& Bertozzi (1998) menyatakan terjadinya asimetri informasi antara eksekutif (kepala daerah) dan legislative (DPRD) menjadi tidak banyak berarti tatkala DPRD menggunakan discretionary powernya dalam penganggaran. Agen mempunyai informasi lebih banyak tentang kinerja keuangan, motivasi, dan tujuan, yang berpotensi menciptakan moral hazard dan adverse selection (Schillemans \& Busuioc, 2015).

Prinsipal sendiri harus mengeluarkan biaya (costs) untuk memonitor kinerja agen dan menentukan struktur insentif dan monitoring yang efisien. Adanya asimetri informasi di antara kepala daerah-DPRD (kepala daerah-didukung mayoritas DPRD separtai) dan DPRD-pemilih menyebabkan terbukanya ruang bagi terjadinya perilaku oportunistik dalam proses penyusunan anggaran pendapatan dan belanja daerah (APBD) Abdullah \& Asmara (2006). Masalah keagenan yang timbul di kalangan kepala daerah terutama incumbent (kepala daerah-didukung mayoritas DPRD separtai) cenderung memaksimalkan kepentingannya (self-interest) dalam pembuatan atau penyusunan APBD, karena memiliki keunggulan data, informasi, dan akses politik. Akibatnya kepala daerah (incumbent) cenderung melakukan budgetary slack. Hal ini terjadi karena kepala daerah ingin mengamankan statusnya dalam pemerintahan dan masyarakat (voter). Salah satu cara penggalangan dana untuk pengamanan kekuasaan adalah melakukan budgetary slack. Budgetary slack APBD lebih banyak untuk kepentingan pribadi atau oportunistik kepala daerah dibandingkan untuk kepentingan masyarakat Abdullah (2012) dan Suartini et al. (2016).

Pemerintah daerah sebagai salah satu organisasi sektor publik (OSP) di Indonesia secara sadar ataupun tidak telah mempraktekan teori keagenan. Hal ini berlaku sejak diberlakukannya UU No. 22 tahun 1999 tentang Pemerintah Daerah dan diperkuat UU No. 25 tahun 1999 tentang Perimbangan Keuangan antara Pemerintah Pusat dan Daerah. Undang-undang ini kemudian telah mengalami beberpa perubahan dan penyempurnaan ditahuntahun berikutnya, seperti UU No.32 tahun 2004 tentang Pemerintah Daerah yang direvisi dengan UU No. 23 tahun 2014 dan UU No. 33 tahun 2004 tentang Perimbangan Keuangan antara Pemerintah Pusat dan Daerah. Otonomi daerah menurut UU No. 23 tahun 2014 adalah hak, wewenang, dan kewajiban daerah otonom untuk mengatur dan mengurus sendiri urusan pemerintahan dan kepentingan masyarakat setempat dalam wadah Negara Kesatuan Republik Indonesia. Pengurusan dan pengaturan rumah tangga sendiri, pemerintah daerah perlu menyusunan, membuat atau meubah anggaran. Dalam proses penyusunan dan perubahan anggaran daerah, ada dua perspektif yang dapat ditelaah dalam aplikasi teori keagenan, yaitu hubungan antara eksekutif (kepala daerah) dengan legislative (DPRD), dan legislative (DPRD) dengan pemilih (voter) atau rakyat. DPRD merupakan pihak priciple bagi kepala daerah namun juga sebagai agen bagi pemih (voter).

Oportunisme merupakan suatu paham yang semata-mata hendak mengambil keuntungan untuk diri sendiri dari kesempatan yang ada tanpa berpegang pada prinsip tententu (KBBI., 2001). Abdullah \& Asmara (2006); Abdullah (2012) menjelaskan opotunistik merupakan perilaku yang berusaha mencapai keinginan dengan segala cara bahkan cara curang sekalipun. Jika dikaitkan dengan pemilukada serentak 2015, incumbent, dan APBD maka oportunistik adalah tindakan atau perilaku yang dilakukan oleh calon kepala daerah (incumbent) untuk mengambil keuntungan tertentu terkait dengan kewenangan yang dimiliki untuk memanfaat APBD untuk kepentingan melanggengkan tapuk pimpinannya. Menurut (Garamfalfi, 1997), politisi akan menggunakan kekuasaannya untuk menentukan alokasi sumber daya, demi keuntungan pribadi politisi. Realisasi perilaku opportunistic eksekutif pada 
proses pengusulan belanja antara lain: 1) Mengusulkan kegiatan yang sesungguhnya tidak menjadi prioritas. 2)Mengusulkan kegiatan yang memiliki lucrative opportunities (peluang untuk mendapatkan keuntungan pribadi) yang besar. 3) Mengalokasikan komponen belanja yang tidak penting dalam suatu kegiatan. 4) Mengusulkan jumlah belanja yang terlalu besar untuk komponen belanja dan anggaran setiap kegiatan. 5) Memperbesar anggaran untuk kegiatan yang sulit diukur hasilnya.

Kepala daerah sebagai politisi akan merubah prioritas APBD dan melakukan aktivitas belanja daerah mendekati waktu pemilukada. Ini adalah sarana yang legal dan halus bagi incumbent untuk melakukan perilaku oportunisme. Disamping itu, incumbent atau kepala daerah dapat merubah alokasi anggaran secara legal. Perilaku oportunistik kepala daerah saat perubahan prioritas APBD dapat mengakibatkan terjadinya ketidak tepatan alokasi anggaran belanja pemerintah daerah. Hal ini membuka peluang bagi kepala daerah untuk merekomendasikan penambahan anggaran bagi program dan kegiatan yang mendukung kegiatan politiknya (Fathony, 2011). Proporsi PAD yang ratarata hanya 10 persen dari total penerimaan daerah memiliki kecenderungan bertambah saat perubahan anggaran.

Pihak-pihak yang terlibat dalam proses penyusunan anggaran memiliki kecenderungan untuk memaksimalkan utilitasnya melalui pengalokasian sumberdaya dalam anggaran Magner, Johnson, Little, Staley, \& Welker (2006). Sedangkan menurut Smith \& Bertozzi (1998) eksekutif atau agency sebagai pengusul anggaran dan juga pelaksana atau pengguna dari anggaran tersebut berupaya untuk memaksimalkan jumlah anggaran. Krenn (2017) menjelaskan pihak agen memiliki informasi lebih daripada pihak principle, sehingga pihak agen bisa memanfaatkan kepentingan pribadi dan politiknya karena memiliki keunggulan kekuasaan.

Politisi cenderung mendukung proyek tertentu yang bukan prioritas pembangunan, karena politisi menerima keuntungan dari proyek tersebut MartinezVazquez, Boex, \& Granado, (2006). Sedangkan (Mitchell, 2000) menyatakan pemerintah lebih cenderung ke proyek yang menguntungkan dirinya dan memiliki nilai di mata pemilihnya atau pendukungnya, seperti infrastruktur (EnnserJedenastik, 2016). Hal senada diungkap oleh Fischer \& Krimmer (2018) bahwa politisi lebih menyukai proyek infrastruktur karena dapat digunakan sebagai bentuk pemenuhan janji-janji kepada pendukung atau pemilih (voter) di era ICT (Information and Communication Technology) saat ini. ICT dan proyek infrastruktur dapat mendekatan hubungan pemilih dan politisi (Fischer \& Krimmer, 2018).

PAD terdiri dari hasil pajak daerah, retribusi daerah, dan pendapatan dari laba perusahaan daerah. PAD merupakan unsur utama penerimaan dalam APBD suatu kabupaten/kota. Perubahan PAD berpengaruh terhadap perilaku oportunistik Abdullah \& Asmara (2006). (Maryono, 2013) menemukan bukti empiris bahwa perubahan PAD akan berpengaruh pada perilaku oportunistik penyusun anggaran yang terdiri dari kepala daerah (eksekutip) dan DPRD sebagai pihak legislatif. Legislatif akan mendorong eksekutif untuk memperbesar target pendapatan sehingga dapat meningkatkan alokasi anggaran untuk program yang mendukung kepentingannya Suartini et al. (2016).

Pemerintah sebagai agen akan menyusun anggaran pendapatan dan mengalokasikan belanja yang lebih besar untuk bidang-bidang tertentu sesuai preferensinya apabila terjadi peningkatan jumlah PAD. Secara konseptual, perubahan pendapatan akan berpengaruh pada belanja atau pengeluaran, namun tidak selalu seluruh tambahan pendapatan tersebut akan dialokasikan dalam belanja Abdullah (2012). Hasil penelitian Abdullah \& Asmara (2006) menyatakan bahwa adanya perbedaan preferensi antara eksekutif dan legislative dalam pengalokasian spread PAD ke dalam belanja sektoral. Penelitian yang dilakukan Jumaidi (2014) dan Ritonga \& Alam (2010) menunjukkan bahwa incumbent mengalokasikan dana untuk kepentingan mereka melebihi jumlah yang diperbolehkan dalam peraturan tersebut. Berdasarkan uraian di atas maka dapat dirumuskan hipotesis,

$\mathrm{H}_{1}$ : PAD berpengaruh positif pada oportunistik incumbent dalam penyusun anggaran setahun sebelum pemilukada 2017.

DAU merupakan sejumlah dana yang dialokasikan Pemerintah Pusat kepada setiap Daerah Otonom(Provinsi/Kabupaten/Kota) di Indonesia setiap tahunnya sebagai dana pembangunan. DAU merupakan salah satu komponen belanja pada APBN, dan menjadi salah satu komponen pendapatan pada APBD. Dana Alokasi Umum (DAU) dialokasikan untuk provinsi dan kabupaten/ kota. Tujuan transfer DAU adalah sebagai pemerataan kemampuan keuangan antar daerah 
untuk mendanai kebutuhan Daerah Otonom dalam rangka pelaksanaan desentralisasi.

DAU untuk suatu daerah dialokasikan berdasarkan formula yang terdiri atas celah fiskal dan alokasi dasar. Celah fiskal merupakan selisih antara kebutuhan fiskal dan kapasitas fiskal. Kebutuhan fiskal diukur dengan menggunakan variabel jumlah penduduk, luas wilayah, Indeks Kemahalan Konstruksi, Produk Domestik Regional Bruto per kapita, dan Indeks Pembangunan Manusia. Sedangkan kapasitas fiskal diukur berdasarkan Pendapatan Asli Daerah dan Dana Bagi Hasil. Alokasi dasar dihitung berdasarkan jumlahgaji Pegawai Negeri Sipil Daerah. DAU memiliki proporsi yang cukup tinggi dalam APBD dengan ratarata 45,4 persen dari total pendapatan daerah. Besaran nilai DAU yang diterima masing-masing daerah cenderung meningkat setiap tahun. Kondisi ini menjadi celah tersendiri bagi penyusun anggaran untuk mengalokasikan dana tersebut untuk membiayai belanja sesuai preferensi yang menguntungkan pihak tertentu. Ritonga \& Alam (2010) menunjukkan bahwa Dana Alokasi Umum berpengaruh positif terhadap alokasi Belanja Modal. Dana Alokasi Umum mempunyai pengaruh positif dan signifikan terhadap belanja langsung.

Penggunaan DAU cukup fleksibel dan tidak terikat dengan program pengeluaran tertentu Maryono (2013). Peningkatan jumlah DAU memberi peluang untuk mengusulkan alokasi belanja baru Sularso, Restianto, \& Istiqomah (2014). Oktariniatmaja, (2011) menyatakan bahwa DAU berpengaruh positif terhadap peningkatan alokasi belanja modal. Penelitian Parwati (2015); Suartini et al. (2016) menyatakan terdapat pengaruh positif DAU pada perilaku oportunistik penyusun anggaran. Berdasarkan uraian hasil penelitian maka dapat dirumuskan hipotesis:

$\mathrm{H}_{2}$ : DAU berpengaruh positif pada oportunistik incumbent dalam penyusun anggaran setahun sebelum pemilukada 2017.

Sisa Lebih Pembiayaan Anggaran (SiLPA) atau Sisa Kurang Pembiayaan Anggaran (SiKPA) adalah selisih lebih/kurang antara realisasi pendapatan-LRA dan belanja, serta penerimaan dan pengeluaran pembiayaan dalam APBN/APBD selama satu periode pelaporan (PP 71 2010). SiLPA yang relatif tinggi mengindikasikan belum optimalnya pemanfaatan dana APBD oleh Pemda dalam penyediaan layanan publik dan pembangunan ekonomi di daerah. SiLPA relatif tinggi terjadi karena senjangan anggaran (budgetary slack) baik di sisi pendapatan maupun belanja. Penetapan target PAD relatif moderat yang dimaksudkan untuk mengamankan kepastian sumber pendanaan belanja daerah atau agar mendapatkan penilaian kinerja yang baik karena realisasi PAD lebih besar dari targetnya. Penetapan belanja terjadi karena penetapan pagu belanja daerah yang optimis untuk mengantisipasi adanya pemotongan anggaran atau untuk mengakomodir adanya penerimaan lain yang salah satunya adalah SiLPA tahun sebelumnya. Penyusun anggaran mempunyai kecenderungan melakukan mark-up belanja dan mark-down pendapatan, sehingga efisiensi yang ditunjukkan dari besaran SiLPA hanya bersifat semu ketika output anggaran tidak tercapai.

Sularso et al. (2014) menyatakan mekanisme perubahan APBD menjadi sarana legal untuk menganggarkan kembali SiLPA tahun sebelumnya. SiLPA dapat dialokasikan untuk belanja sesuai preferensi penyusun anggaran sehingga membuka ruang terjadinya perilaku oportunistik. Florensia (2009) menyatakan SiLPA tidak berpengaruh terhadap perilaku oportunistik. SiLPA berpengaruh terhadap perilaku oportunistik penyusun anggaran Kabupaten/Kota di Provinsi Jawa Tengah Fathony (2011). Menurut Musripah (2014) SiLPA berpengaruh positif terhadap Perilaku Oportunistik Penyusun Anggaran di Kabupaten/Kota di Provinsi Jawa Timur. Demikian juga, Suartini et al.(2016) dan Parwati (2015) menyatakan bahwa SiLPA berpengaruh positif pada perilaku oportunistik penyusun anggaran. Tetapi hasil berbeda dinyatakan oleh Ritonga \& Alam (2010) dimana SiLPA berpengaruh positif terhadap belanja modal pada periode anggaran selanjutnya. Berdasarkan uraian di atas maka dapat dirumuskan hipotesis.

$\mathrm{H}_{3}$ : SiLPA berpengaruh positif pada oportunistik incumbent dalam penyusun anggaran setahun sebelum pemilukada 2017.

Prasojo $(2009 ; 186)$ menyatakan dalam banyak hal, pemilihan langsung kepala daerah dan pemisahan yang tegas antara mayor (kepala daerah) dan councilor (anggota DPRD) di negara-negara berkembang telah menyebabkan praktek-praktek pemerintahan yang semakin buruk. Faktor utamanya adalah karakteristik elite lokal yang kooptatif dan selalu menutup kesempatan pihak lain untuk berkompetisi dalam politik, pengetahuan dan 
kesadaran politik rakyat yang rendah, serta tidak adanya pengawasan yang terus-menerus dari DPRD terhadap kepala daerah Sarman (2015). Selanjutnya dipertegas oleh (Prasojo, 2009) bahwa fakor-faktor tersebut juga terefleksikan di beberapa daerah di Indonesia. Kooptasi kekuasaan dilakukan oleh calon incumbent dengan memanfaatkan akses birokrasi yang dimilikinya.

Hasil penelitian yang dilakukakan oleh Indonesiaan Corruption watch (ICW) bekerjasama dengan Universitas Murdoch (Kompas, 14 April 2009) menemukan adanya peningkatan alokasi belanja hibah dan bantuan sosial dalam APBD pada saat pelaksanaan pemilukada tahun $2008 \mathrm{di}$ Kabupaten Tabanan (Bali), Kota Bau-Bau (Sulawsesi Tenggara), dan Kota Bandung (Jawa Barat) diikuti dengan kemenangan incumbent.

Penelitian Ritonga \& Alam (2010) dan Suartini et al. (2016) menjelaskan bahwa ada peningkatan dana bantuan sosial, dan hibah pada saat pemilikada jika dibandingkan dengan sebelum pemilukada. Hal yang sama juga terjadi jumlah bantuan sosial dan hibah yang lebih besar di daerah yang calon merupakan incumbent jika dibadingkan dengan daerah yang calon kepala daerahnya bukan incumbent. Dari hal tersebut maka hipotesis yang diajukan adalah:

$\mathrm{H}_{4}$ : Terdapat perbedaan perilaku oportunistik antara incumbent yang menang dan kalah dalam penyusun anggaran setahun sebelum pemilukada.

$\mathrm{H}_{5}$ : Terdapat perbedaan perilaku oportunistik incumbent dalam penyusun anggaran setahun sebelum dan saat pemilukada.

\section{METODE PENELITIAN}

Populasi penelitian ini adalah seluruh Kabupaten, Kota dan Provinsi di Indonesia yang mengikuti pemilukada serentak tahun 2017. Data Komisi Pemilihan Umum (KPU) menunjukan sebanyak 93 kabupaten, kota, dan provinsi mengikuti pemilukada serentak tahun 2017. Teknik penyampelan dalam penelitian ini adalah purposive sampling. Kriteria yang digunakan adalah 1) Kabupaten, kota dan provinsi menyampaikan APBD dan RAPBD tahunan kepada Direktorat Jendral Perimbangan Keuangan Pemerintah Daerah Tahun 2014-2017. 2) Kabupaten, kota dan provinsi di Indonesia yang melaporkan secara rutin APBD dan RAPBD dari sektor pendidikan, kesehatan, infrastruktur, hibah dan bansos selama empat tahun yaitu tahun 2014-2017.
3) Kabupaten, kota dan provinsi di Indonesia yang melaporkan secara rutin APBD dan RAPBD tahun anggaran 2014-2017 dan mempublikasikan PAD, DAU dan SiLPA.

Peneliti menggunakan tahun penelitian 20142017, guna melihat realisasi APBD sebelum pemilukada serentak tahun 2017, yaitu tahun 2014, 2015, 2016 dan saat pemilukada 2017 menggunakan data RAPBD 2017. Incumbent disinyalir meningkatkan pos-pos belanja dalam APBD sesuai dengan kepentingannya untuk modal kampanye pada tahun politik (satu sampai dua tahun sebelum pemilukada).

Variabel dependen Oportunistik incumbent (OPI) didefiniskan sebagai perilaku yang berusaha mencapai keinginan dengan segala cara yang dapat menyebabkan hubungan incumbent-DPRD-pemilih (voter) atau principel-agen dalam suatu kontrak yang akhirnya mengarah terjadinya adverse selection dan moral hazard. Pengukuran Oportunistik incumbent Abdullah \& Asmara (2006) dilakukan dengan dua tahap, yaitu menghitung variance alokasi anggaran belanja pendidikan, belanja kesehatan, belanja infrastruktur, belanja hibah dan belanja bansos dan kedua menghitung variance $=$ APBD tahun berjalan - APBD tahun sebelumnya. Terakhir, mengakumulasikan variance yang menunjukkan Oportunistik incumbent (OPI). Penurunan alokasi untuk belanja pendidikan dan kesehatan menunjukkan perilaku oportunistik incumbent, begitu pula penurunan atau kenaikan anggaran untuk infrastruktur, hibah dan bansos.

Rumus OPI secara keseluruhan adalah:.

$\mathrm{OPI}=\Delta \mathrm{Pdk}+\Delta \mathrm{Kes}+\Delta \mathrm{Inf}+\Delta \mathrm{Hibah}+\Delta$ Bansos

Keterangan :

$\Delta \mathrm{Pdk} \quad$ : penurunan alokasi untuk belanja pendidikan

$\Delta$ Kes : penurunan alokasi untuk belanja kesehatan

$\Delta$ Inf : kenaikan alokasi untuk belanja infrastruktur

$\Delta$ Hibah : kenaikan alokasi untuk belanja hibah $\Delta$ Bansos : kenaikan alokasi untuk belanja bansos

Tiga variabel independen penelitian ini, yaitu PAD, DAU dan SiLPA. PAD adalah Pendapatan Asli Daerah yang terdiri dari hasil pajak daerah, retribusi daerah, dan pendapatan dari laba perusahaan daerah. Cara mengukur PAD adalah dengan menggunakan variance atau delta PAD (D PPAD) 
adalah perubahan naik atau turunnya PAD dari APBD tahun berjalan (t) ke APBD tahun sebelumnya ( $\mathrm{t}-1)$.

Dana Alokasi Umum (DAU), berdasarkan UU No. 33 Tahun 2004 adalah dana yang berasal dari APBN, yang dialokasikan dengan tujuan pemerataan kemampuan keuangan antar daerah untuk membiayai kebutuhan pengeluarannya dalam rangka pelaksanaan desentralisasi. DAU untuk masingmasing $\mathrm{Kab} /$ Kota dapat dilihat dari pos dana perimbangan dalam Laporan Realisasi APBD 2014, 2015, dan 2016 dan RAPBD untuk tahun 2017. DAU diukur dengan variance atau delta Dana Alokasi Umum ( $\triangle \mathrm{DAU})$ dari APBD tahun berjalan $(\mathrm{t}) \mathrm{ke}$ APBD tahun sebelumnya (t-1) (Abdullah, 2012).

Sisa Lebih Perhitungan Anggaran (SiLPA) mencakup kelebihan atau sisa lebih penerimaan $\mathrm{PAD}$, penerimaan dana perimbangan, penerimaan lain-lain pendapatan daerah yang sah, penerimaan pembiayaan, penghematan belanja, kewajiban kepada pihak ketiga sampai dengan akhir tahun terselesaikan dan sisa dana kegiatan lanjutan. SiLPA diukur dengan variance atau delta $\operatorname{SiLPA}(\Delta \operatorname{SilPA})$ tahun berjalan $(\mathrm{t})$ - SiLPA tahun sebelumnya $(\mathrm{t}-1)$.

Alat yang digunakan untuk menguji hipotesis 1,2,dan 3 adalah analisis regresi berganda. Pengujian dengan analisis regresi berganda memerlukan syarat pengujian asumsi klasik sebagai alat untuk melihat kesesuaian data. uji asumsi klasik yang digunakan adalah uji normalitas, uji multikoloniearitas, uji heteroskedastisitas, dan uji autokorelasi. Adapun rumus regresi berganda:

$\mathrm{Y}=\alpha+\beta_{1} \mathrm{X}_{1}+\beta_{2} \mathrm{X}_{2}+\beta_{3} \mathrm{X}_{3}+\varepsilon$
Keterangan :

Y : Perilaku Oportunistik incumbent saat penyususnan anggaran

$\mathrm{X}_{1}$ : Pendapatan Asli Daerah (PAD)

$\mathrm{X}_{2}$ : Dana Alokasi Umum (DAU)

$\mathrm{X}_{3}$ : Sisa lebih Perhitungan Anggaran (SiLPA)

$\alpha$ : Konstanta.

$\beta$ : Koefisien Regresi.

$\varepsilon$ : error.

Jika hasil regresi menunjukkan nilai signifikansi $<0,05$, maka hipotesis 1,2 dan 3 diterima. Hal ini menyatakan bahwa variable independen secara individual berpengaruh pada variabel dependen Ghozali (2011).

Pengujian hipotesis 4 dan 5 menggunakan uji beda $t$-Test. Pengujian digunakan untuk melihat perbedaan perilaku oportunistik incumbent, baik satu tahun sebelum dan saat pemilukada serentak tahun 2017 dan incumbent terpilih dan tidak terpilih kembali pada pemilukada 2017. Data diolah dengan program statistical package for science (SPSS Ver 24).

\section{HASIL DAN PEMBAHASAN}

Pemilukada serentak tahun 2017 diikuti sembilan puluh tiga kabupaten, kota dan provinsi di Indonesia. Pemilukada tahun 2017 adalah pemilukada kedua yang dilakukan serentak di Indonesia. Pemilukada serentak pertama dilakukan tahun 2015, kedua tahun 2017 dan ketiga tahun 2018. Data pasangan calon pemilukada 2017 , terlihat pada Tabel 1 .

Tabel 1. Jumlah Pasangan Calon Bupati, Walikota dan Gubernur Pemilukada 2017

\begin{tabular}{lcccc}
\hline \multicolumn{1}{c}{ Jenis Pemilihan } & Jumlah & \multicolumn{2}{c}{ Asal Pasangan calon } & \multirow{2}{*}{ Total } \\
& Wilayah & Perseorangan & Partai Politik & 7 \\
\hline Gubernur & 7 & - & 65 & 68 \\
Bupati & 68 & 3 & 18 & 18 \\
Walikota & 18 & - & 90 & 93 \\
\hline \multicolumn{1}{c}{ Jumlah } & 93 & 3 & & \\
\hline
\end{tabular}

\section{Sumber: KPU 2017}

Pemilukada serentak tahun 2017 mempunyai agenda pemilihan tujuh gubernur, enampuluh delapan bupati, dan delapan belas walikota. Peserta pemilukada berasal dari pasangan calon yang berasal dari perseorangan terdapat di tiga kabupaten dan sisanya (sembilan puluh walikota dan gubernur) diajukan oleh partai politik. Hal ini menujukan peran partai politik (tereprentasi di DPRD) pada pemilihan kepala daerah yang sangat dominan, besar dan menentukan kepala daerah yang bisa maju di pemilukada tahun 2017.

Pasangan calon pemilukada tahun 2017 masih didominasi oleh laki-laki seratus tujuh puluh satu (92 persen), sedangkan sisanya lima belas ( 8 persen) berjenis kelamin perempuan. Data rekapitulasi jenis kelamin pasangan calon terlihat pada Tabel 2. 
Tabel 2. Rekapitulasi Pasangan Calon Berdasarkan Jenis Kelamin

\begin{tabular}{|c|c|c|c|c|c|c|}
\hline \multirow{2}{*}{$\begin{array}{c}\text { Jenis } \\
\text { Pemilihan }\end{array}$} & \multicolumn{2}{|c|}{ Calon Kepala Daerah } & \multicolumn{2}{|c|}{ Calon Wakil Kepala Daerah } & \multicolumn{2}{|c|}{ Total } \\
\hline & Laki-Laki & Perempuan & Laki-Laki & Perempuan & Laki-Laki & Perempuan \\
\hline Gubernur & 7 & - & 6 & 1 & 13 & 1 \\
\hline Bupati & 60 & 8 & 65 & 3 & 125 & 11 \\
\hline Walikota & 16 & 2 & 17 & 1 & 33 & 3 \\
\hline Jumlah & 83 & 10 & 88 & 5 & 171 & 15 \\
\hline
\end{tabular}

Sumber: KPU 2017

Tabel 2 menunjukan calon gubernur dan wakil gubernur berjenis kelamin laki-laki tiga belas dan satu wakil gubernur berjenis kelamin perempuan. Pemilihan calon bupati dan wakil bupati berjenis kelamin laki-laki seratus dua puluh lima dan sebelas berjenis kelamin perempuan. Pasangan calon walikota berjenis kelamin laik-laki tiga puluh tiga orang sedangkan perempuan sebanyak tiga calon. Hal ini masih menunjukan masih kurangnya peran perempuan dalam pemilihan kepala daerah di Indonesia. Hal ini terkait dengan keberanian kepala daerah untuk mengambil resiko (sifat maskulin dan feminin) dalam membuat keputusan terutama pengalihan mata anggaran yang tidak sesuai pos anggaran yang telah ditetapkan di APBD.

Latar belakang atau pekerjaan pasangan calon kepala daerah sebelum maju pada pemilukada 2017, terlihat pada Tabel 3 .

Tabel 3. Rekap Pekerjaan Pasang Calon Kepala Daerah

\begin{tabular}{|c|c|c|c|c|c|c|c|}
\hline \multirow[b]{2}{*}{ Pekerjaan } & \multirow[b]{2}{*}{ Gubernur } & \multicolumn{5}{|c|}{ Calon } & \multirow[b]{2}{*}{ Total } \\
\hline & & $\begin{array}{c}\text { Wakil } \\
\text { Gubernur }\end{array}$ & Bupati & $\begin{array}{c}\text { Wakil } \\
\text { Bupati }\end{array}$ & Walikota & $\begin{array}{c}\text { Wakil } \\
\text { Walikota }\end{array}$ & \\
\hline Petahana & 1 & 1 & 27 & 19 & 9 & 6 & 63 \\
\hline Non Petahana & 6 & 6 & 33 & 57 & 9 & 12 & 123 \\
\hline Jumlah & 7 & 7 & 60 & 76 & 18 & 18 & 186 \\
\hline
\end{tabular}

Sumber: KPU 2017

Pemilukada 2017 diikuti oleh enam puluh tiga calon (33 persen) adalah incumbent atau petahana, sedangkan seratus dua puluh tiga calon (67 persen) kepala dan wakil kepala daerah yang sebelumnya bukan sebagai petahana atau incumbent. Petahana sejumlah enam puluh dua pasangan calon, kedudukan sebelumnya tiga puluh tujuh kepala daerah dengan kondisi enam belas calon berpasangan dengan wakilnya, tiga belas calon tidak berpasangan dengan wakilnya dan delapan calon pecah kongsi dengan wakilnya dan saling bertarung. Petahana sejumlah dua puluh lima sebagai wakil kepala daerah dengan kondisi enam belas calon berpasangan dengan kepala daerah sebelumnya, tiga calon pecah kongsi dengan kepala daerah dan bertarung pada pemilukada, dan enam calon tidak berpasangan dengan kepala daerah dan tidak saling bertarung (Jawa Pos, 27 Februari 2017 dan KPU 2017). Pemilukada serentak 2017 diikuti sembilan puluh tiga pasangan calon kepala daerah dimenangkan oleh petahana sebanyak tiga puluh tujuh kepala daerah atau (59 persen) petahana (dari enam puluh tiga petahana yang ada). Hal ini menjadi menarik untuk dikaji terkait dengan opportunism incumbent dalam menyusun APBD atau RAPBD terkait dengan tahun politik demi mempertahankan kedudukannya sebagai kepala daerah.

Pengujian hipotesis pertama, kedua dan ketiga menggunakan regresi linier berganda. Sebelum melakukan analisis regresi linier berganda harus dilakukan pengujian asumsi klasih terhadap data yang diolah. Uji asumsi klasik yang digunakan adalah uji normalitas, uji multikoloniearitas, uji autokorelasi dan uji heteroskedastisitas. Setelah dilakukan pengujian data telah lolos dari uji asumsi klasik, sehingga bisa dilanjutkan ke pengujian dengan regresi linier berganda. Tabel 4 adalah hasil pengujian dengan regresi linier berganda.

Hasil pengujian hipotesis dengan regresi linier berganda pada Tabel 4 mengindikasikan model yang diformulasikan tergolong handal digunakan untuk pengujian hipotesis dengan nilaiadjusted $\mathrm{R} 2=91,7 \%$; $F$-value $=341,527$ dan signifikan pada $p$-value $=0,000$.

Variabel pendapatan asli daerah (PAD) berpengruh terhadap oportunistik incumbent (OPI) dengan signifinaksi a $<0,05$ ( $p$-value $=0,000)$ dengan nilai koefisien $b_{1}$ bertanda positif sebesar 3,140 . Hal ini mengindikasikan bahwa semakin meningkat 
Tabel 4. Pengujian Hipotesis dengan Regresi Linier Berganda

\begin{tabular}{|c|c|c|c|c|}
\hline Hipotesis & Variabel Dependen & Variabel Independen & B & $\begin{array}{c}\text { Level } \\
\text { Signifikansi }\end{array}$ \\
\hline $\mathrm{H}_{1}$ & $\begin{array}{l}\text { Oportunistik Incumbent } \\
\text { (OPI) }\end{array}$ & $\begin{array}{l}\text { Pendapatan Asli Daerah } \\
\text { (PAD) }\end{array}$ & 3,140 & 0,000 \\
\hline $\mathrm{H}_{2}$ & $\begin{array}{l}\text { Oportunistik Incumbent } \\
\text { (OPI) }\end{array}$ & Dana Alokasi Umum (DAU) & 0,005 & 0,914 \\
\hline $\mathrm{H}_{3}$ & $\begin{array}{l}\text { Oportunistik Incumbent } \\
\text { (OPI) }\end{array}$ & $\begin{array}{l}\text { Sisa lebih Perhitungan } \\
\text { Anggaran (SiLPA) }\end{array}$ & 0,990 & 0,006 \\
\hline Constant & 1,190 & & & \\
\hline Adjusted $\mathrm{R}^{2}$ & 0,917 & & & \\
\hline F Value & 341,527 & & & \\
\hline P Value/Sig & 0,000 & & & \\
\hline
\end{tabular}

Sumber: Data diolah, 2018

pendapatan asli daerah (PAD) pada tahun minus satu pemilukada maka semakin besar peluang incumbent melakukan oportunistik APBD atau RAPBD-nya. Peningkatan PAD dari tahun sebelumnya ke tahun berjalan mempengaruhi alokasi belanja sektor-sektor tertentu yang dapat memberikan manfaat besar bagi penyusun dan pengusul anggaran.

Dengan demikian, hipotesis $\mathrm{H}_{1}$ pada penelitian ini dapat dinyatakan terdukung oleh data empiris. Temuan ini konsisten dengan penelitian Magner et al. (2006); Smith \& Bertozzi (1998); Sularso et al. (2014), dan Suartini et al. (2016) menjelaskan pihakpihak yang terlibat dalam penyususnan anggaran cenderung memaksimalkan utilitasnya melalui pengalokasian belanja anggaran, apalagi pihak eksekutif sebagai pengusul anggaran mempunyai infomasi lebih banyak jika dibanding dengan pihak legislatif.

Hasil ini juga bisa diinterprestasikan bahwa eksekutif akan memperbesar target pendapatan (PAD) dengan tujuan untuk meningkatkan alokasi anggaran untuk program-program yang menyentuh ke pendukungnya (voter). PAD merupakan jalan bagi penyusun anggaran untuk melakukan political corruption dalam kerangka regulasi yang sah (legal corruption). Fenomena ini terlihat ketika perubahan anggaran atau target PAD digunakan sebagai dasar untuk melakukan alokasi tambahan belanja. Penyusun anggaran (eksekutif) dan penyetuju anggaran (legislatif) akan berusaha mengalokasikan dana yang lebih besar untuk bidang-bidang tertentu sesuai preferensinya yang bersinggungan langsung dengan voternya (seperti belanja pendidikan, kesehatan, infrastruktur dan hibah) apabila terjadi peningkatan juga jumlah APBD dan RAPBD-nya secara signifikan.

Variabel Dana Alokasi Umum (DAU) tidak berpengruh terhadap oportunistik incumbent (OPI) dengan signifinaksi $\alpha>0,05(p$-value $=0,914)$ dengan nilai koefisien $\beta_{1}$ bertanda positif sebesar 0,005 . Hal ini mengindikasikan bahwa semakin meningkat dana alokasi umu (DAU) pada tahun minus satu pemilukada maka belum tentu atau belum pasti meningkatkan peluang incumbent melakukan oportunistik APBD atau RAPBD-nya. Dengan demikian, hipotesis $\mathrm{H}_{2}$ pada penelitian dinyatakan belum atau tidak terdukung oleh data empiris. Temuan ini berbeda dengan penelitian Parwati (2015) dan Suartini et al.(2016) yang menjelaskan bahwa DAU mempunyai pengaruh positif dan signifikan terhadap perilaku oportunistik penyusun anggaran.

DAU merupakan dana yang bersumber dari APBN yang bertujuan untuk meningkatkan pemerataan dan kemampuan keuangan antar daerah atau mengurangi ketimpangan kemampuan antar daerah dengan melalui penerapn formula tertentu. DAU suatu daerah ditentukan dari alokasi dasar dan besar kecilnya celah fiscal (fiscal gap) suatu daerah. Alokasi dasar dihitung berdasrkan jumlah gaji pegawai negeri sipil (belanja pewawai daerah) di daerah yang bersangkutan. Sedangkan celah fiscal merupakan selisih antara kebutuhan daerah (fiscal need) dan potensi daerah. Selain itu, hasil penelitian berbeda dengan penelitian sebelumnya karena menggunakan tahun amatan satu tahun sebelum pemilukada sehingga perubahan belanja pendidikan, kesehatan, infrastruktur dan hibah lebih besar dibanding dengan perubahan DAU.

Indonesia Corruption Watch menyebut dari lima terbesar objek dana yang rentan dikorupsi salah satunya adalah Dana Alokasi Khusus (DAK) pendidikan. Berdasarkan fenomena, DAK pendidikan tidak dimanfaatkan untuk menutup kesenjangan pelayanan publik di bidang pendidikan tetapi dipakai memenuhi kepentingan para kepala daerah untuk memenuhi kebutuhan voternya. Hal ini dibuktikan 
dengan banyaknya penyimpangan Dana Alokasi Khusus (DAK) pendidikan yang melibatkan pejabat kepala daerah untuk kepentingan dirinya sendiri. Terdapat indikasi dana korupsi proyek DAK pendidikan turut mengalir dalam pemilihan kepala daerah (Pilkada). Skenario pemanfaatan dana proyek dibidang pendidikan dirancang masuk melalui Kepala Dinas (Kadis) sebagai balas jasa atas pengangkatan Kadis oleh kepala daerah incumbent.

Variabel sisa lebih anggaran (SiLPA) berpengruh terhadap oportunistik incumbent (OPI) dengan signifinaksi $\alpha<0,05$ ( $p$-value $=0,006)$ dengan nilai koefisien $\beta_{1}$ bertanda positif sebesar 0,990 . Hal ini mengindikasikan bahwa semakin tinggi atau meningkat sisa lebih anggaran (SiLPA) pada tahun minus satu pemilukada, maka akan meningkatkan peluang incumbent melakukan oportunistik APBD atau RAPBD-nya. Dengan demikian, hipotesis $\mathrm{H}_{3}$ pada penelitian dinyatakan didukung oleh data empiris.

Hasil penelitian mendukung pendapat dan hasil penelitian Musripah (2014), Parwati, (2015) dan Suartini et al. (2016) yang menyatakan bahwa SiLPA berpengaruh positif terhadap perilaku oportunistik penyusun anggaran. Hal ini dapat diinterprestasikan jika terdapat SiLPA yang tinggi akan mendorong para penyusun anggaran untuk melakukan perilaku opotunistik penyusun anggaran terutama para incumbent pada pemilukada serentak.

SiLPA sebenarnya merupakan indikator efisiensi, karena SiLPA terbentuk jika terjadi surplus pembiayaan neto. Hal ini berarti komponen penerimaan lebih besar dari komponen pengeluaran pembiayaan. Tetapi, SiLPA besar sangat erat kaitannya karena tingkat serapan yang sangat kecil. Tingkat penyerapan anggaran tergantung juga pada pola perencanaan, baik dalam tataran kebijakan jangka panjang dan kebijakan teknis. Anggaran harus bisa dicairkan sehingga dapat menopang penjabaran tataran kebijakan dan pelaksanaan teknisnya demi kesejahteraan masyarakat. Akan tetapi, SiLPA bisa dimanfaatkan oleh incumbent dan partai pendukungnya di parlemen untuk menyetujui angaran yang bersentuhan langsung dengan pemilihnya (voternya) melalaui pos anggaran belanja pendidikan, kesehatan, infrastruktur dan hibah. Pemanfatan ini biasanya akan dilakukan satu tahun sebelum hajatan pemilukada dilakukan guna melanggengkan kekuasaannya.

SiLPA yang relatif tinggi disebabkan oleh tidak terserapnya seluruh anggaran untuk kesejahteraan masyarakat. Pemerintah daerah merupakan agent atau wakil dari principal atau masyarakat seharusnya melaksanakan APBD dengan baik sehingga tidak menghasilkan SiLPA yang tinggi. Direktorat Jendral Perimbangan Keuangan (www.djkp.kemenkeu.go.id) menyatakan bahwa pembiayaan daerah tidak hanya merupakan imbas selisih pendapatan dan belanja tapi juga sebagai penentu besaran belanja karena sebagian besar penerimaan pembiayaan (lebih dari 90\%) berasal dari SiLPA. SiLPA terlalu tinggi menunjukkan dana publik yang dikelola Pemda tidak digunakan secara optimal untuk penyelenggaraan layanan publik. Penyebab lain tingginya SILPA adalah proses penyusunan anggaran yang memungkinkan SKPD melakukan penggelembungan belanja atau penurunan target penerimaan (budget slack). Penggelembungan belanja maupun penurunan target penerimaan menjadi salah satu penyebab terjadinya sisa anggaran (SILPA), tanpa melihat output kegiatan sudah tercapai atau belum. Ketika output anggaran tercapai, maka sisa anggaran sering disebut sebagai hasil efisiensi dalam kegiatan, sehingga bersifat bebas untuk digunakan bagi kegiatan lain pada tahun anggaran berikutnya.

Pengujian hipotesis ke 4 dan 5 menggunakan uji beda $t$-Test. Hasil pengujian hipotesis ke empat yang menyatakan terdapat perbedaan perilaku oportunistik antara incumbent yang menang dan kalah dalam penyusun anggaran setahun sebelum pemilukada didukung oleh data dengan tingkat signifikan sebesar 0,027 atau kurang dari 0,05. Hal ini menujukan adanya perbedaan perilaku oportunistik antara incumbent yang terpilih kembali dengan yang tidak terpilih kembali setahun sebelum pemilukada 2017. Hal ini bisa dilihat dari jumlah nilai rata-rata dan standar deviasi oportunistik (penjumlahan $\Delta$ pendidikan $+\Delta$ kesehatan $+\Delta$ infrastruktur $+\Delta$ Hibah $+\Delta$ Bansos) setahun sebelum pemilukada 2017. Tabel 5 menjelaskan rata-rata dan standart deviasi OPI incumbent yang menang dan kalah pada pemilukada 2017.

Tabel 5 menunjukan nilai rata pemenang pemilkada menunjukan nilai sebesar 108 milyar sedangkan yang kalah sebesar 624 milyar dengan standar deviasi sebesar 288 milyar dan 3.418 milyar. Hasil ini sesuai dengan Prasojo $(2009 ; 186)$ dan Sarman (2015) yang menyatakan kooptasi kekuasaan dilakukan oleh calon incumbent dengan memanfaatkan akses birokrasi yang dimilikinya dengan memanfaatkan APBD. 
Hasil pengujian hipotesis ke lima yang menyatakan terdapat perbedaan perilaku oportunistik incumbent dalam penyusun anggaran setahun sebelum dan saat pemilukada tidak didukung oleh data dengan tingkat sgnifikansi 0,212 lebh besar dari 0,05 . Hal ini berarti tidak tejadi perbedaan perilaku oprtunisme incumbent setahun sebelum dan saat dilakukan pemilukada tahun 2017. Hal ini bisa dilihat dari jumlah nilai rata-rata dan standar deviasi oportunistik (penjumlahan $\Delta$ pendidikan $+\Delta$ kesehatan $+\Delta$ infrastruktur $+\Delta$ Hibah $+\Delta$ Bansos) setahun sebelum dan saat pemilukada 2017. Tabel 6 menunjukan nilai rata-rata dan standar deviasi OPI sebelum dan saat pemilukada tahun 2017.

Tabel 5. T-Test Incumbent Menang dan Kalah Pada Pemilukada 2017

\begin{tabular}{lllcc}
\hline & \multicolumn{1}{c}{ V4 } & $\mathrm{N}$ & Mean & Std. Deviation \\
\hline \multirow{2}{*}{ OPI_16 } & $\begin{array}{l}\text { Incumbent } \\
\text { Menang }\end{array}$ & 37 & 108303508400.000 & 288346755000.000 \\
\cline { 2 - 5 } & $\begin{array}{l}\text { Incumbent } \\
\text { Kalah }\end{array}$ & 28 & 624660259500.000 & 3418007605000.000 \\
\hline
\end{tabular}

Sumber: Data diolah, 2018

Tabel 6 menunjukan nilai rata setahun sebelum pemilukada menunjukan nilai sebesar 317 milyar sedangkan saat dilakukan pemilukada sebesar minus 71 milyar dengan standar deviasi sebesar 2.162 milyar dan 246 milyar. Penelitian Ritonga \& Alam
(2010) dan Suartini et al. (2016) menjelaskan bahwa ada peningkatan dana bantuan sosial, dan hibah pada saat pemilikada jika dibandingkan dengan sebelum pemilukada.

Tabel 6. T-Test Setahun sebelum dan Saat Pemilukada 2017

\begin{tabular}{|c|c|c|c|c|}
\hline & Inc vs non & $\mathrm{N}$ & Mean & Std. Deviation \\
\hline \multirow{2}{*}{ OPI_16 } & Sebelum & 65 & 317732422600.000 & 2162037042000.000 \\
\hline & Saat & 28 & 71400462000.000 & 246538701500.000 \\
\hline
\end{tabular}

Sumber: Data diolah, 2018

\section{SIMPULAN}

Hasil penelitian menunjukan PAD dan SiLPA berpengaruh pada oportunistik incumbent dalam menyusun APBD setahun sebelum dilakukan pemilukada. Sedangkan DAU tidak berpengaruh terhadap oportunistik incumbent dalam menyusun APBD setahun sebelum dilakukan pemilukada 2017. Hasil uji beda menunjukan bahwa terdapat perbedaan perilaku oportunistik incumbent yang kalah dalam penyusunan APBD setahun sebelum pemilukada. Sedangkan hasil pengujian terakhir menunjukan tidak ada perbedaan perilaku oportunistik incumbent dalam menyusun anggaran setahun sebelum dan saat pemilukada dilakukan tahun 2017.

Hasil penelitian ini memperkuat praktek teori keagenan pada akuntansi sektor publik dan berdampak pada pentingnya strategi manajerial pemilukada serentak di Indonesia. Pemilukada yang sudah dibiayai oleh pemerintah pusat dan daerah dengan biaya tinggi masih ditambah lagi dengan perilaku oportunistik incumbent dalam menyususn
APBD dengan menyusun program-program yang bukan prioritas penyejahteraan masyarakat tetapi difokuskan pada program jangka pendek untuk meningkatkan popularitas incumbent untuk melanggengkan jabatanya sebagai kepala daerah. Penelitian selanjutnya dapat dilakukan analisis perilaku incumbent setelah memenangkan periode kedua dari jabatannya. Hal ini dilakukan karena ada peluang incumbent mempermainkan angka-angka dalam APBD untuk mengembalikan investasi yang dia lakukan selama pemilukada.

\section{REFERENSI}

Abdullah, S. (2012). Perilaku Oportunistik Legislatif dan FAktor-Faktor yang Mempengaruhinya: Studi Empiris dari Penganggaran Daerah di Indonesia. In Ringakasan Disertasi (pp. 1100).

Abdullah, S., \& Asmara, J. A. (2006). Perilaku Oportunistik Legislatif Dalam Penganggaran Daerah Bukti Empiris atas Aplikasi Agency 
Theory di Sektor Publik. In Simposium Nasional Akuntansi 9 Padang (pp. 23-26).

Ban, P., Llaudet, E., \& Snyder, J. M. (2016). Challenger Quality and the Incumbency Advantage. Legislative Studies Quarterly, 4l(1), 153-179. https://doi.org/10.1111/lsq.12109

Ennser-Jedenastik, L. (2016). The Politicization of Regulatory Agencies: Between Partisan Influence and Formal Independence. Journal of Public Administration Research and Theory, 26(3), 507-518. https://doi.org/10.1093/ jopart/muv022

Fathony, A. D. (2011). Pengaruh Pendapatan Asli Daerah, Sisa Lebih Perhitungan Anggaran Dan Dana Alokasi Umum Terhadap Perilaku Oportunistik Penyusun Anggaran (Studi Kasus Kabupaten/Kota Di Provinsi Jawa Tengah). Skripsi Fakultas Ekonomi Universitas Diponegoro Semarang.

Fischer, D.-H., \& Krimmer, R. (2018). Towards a Networked Modern Democracy Thoughts on How ICT Could Enable New Forms for the Relationship Between Citizens and Their Representatives. ACM International Conference Proceeding Series. https://doi.org/ 10.1145/3209281.3209284

Florensia, T. M. (2009). Perilaku Oportunistik Legislatif Dalam Penganggaran Daerah: Bukti Empiris atas Aplikasi Agency Theory di Sektor Publik. Universitas Gajah Mada, Yogyakarta.

Garamfalfi, L. (1997). Corruption in the Public Expenditures Management Process. 8th International Anti-Corruption Conference, Lima, Peru, 1-28.

Ghozali, I. (2011). Aplikasi Analisis Multivariate dengan Program SPSS (Cetakan IV). Semarang: Badan Penerbit Universitas Diponegoro.

Jawa Pos; 10 Agustus 2017. (2017). EksekutifLegislatif Gerogoti Anggaran, p. 2.

Jawa Pos; 27 Februari 2017. (, February). 60 Persen Calon Petahana Unggul. Jawa Pos, p. 2.

Jumaidi, L. (2014). Perilaku legislatif dalam praktik penganggaran dengan pendekatan nilai-nilai kearifan lokal (nilai budaya sasak). Simposium Nasional Akuntansi 17 Mataram Lombok 24 27 September 2014, 1-20.

Klašnja, M. (2015). Corruption and the Incumbency Disadvantage: Theory and Evidence. The Jurnal of Politics, 77(4), 928-942. https://doi.org/ 10.1525/jsah.2012.71.3.273.and

Krenn, C. (2017). The European Court of Justice's Financial Accountability. European Constitutional Law Review, 13(3), 453-474. https://doi.org/10.1017/S1574019617000153

Lalvani, M. (1999). Elections and Macropolicy Signals: Political Budget Cycle Hypothesis, 34(37), 11-17.

Magner, N. R., Johnson, G. G., Little, H. T., Staley, A. B., \& Welker, R. B. (2006). The Case for Fair Budgetary Procedures. Managerial Auditing Journal, 21(4), 408-419. https:// doi.org/10.1108/026869006 10661414

Martinez-Vazquez, J., Boex, J., \& Granado, J. A. del. (2006). Corruption, Fiscal Policy, and Fiscal Management. In Corruption, Fiscal Policy, and Fiscal Management.

Maryono, R. (2013). Pengaruh Perubahan Dana Alokasi Umum Terhadap Perilaku Oportunistik Legislatif Dalam Penganggaran Daerah (Studi Kasus pada Kabupaten/Kota di Sumatera Barat). Tesis Fakultas Ekonomi Universitas Negeri Padang.

Mitchell, P. (2000). Voters and Their Representative: Electoral Institutions and Delegation in Parliamentary Democracies. European Journal of Political Research, (37), 335-351.

Musripah, S. (2014). Pengaruh Perubahan Pendapatan Asli Daerah, Sisa Lebih Perhitungan Anggaran, Dan Dana Alokasi Umum Terhadap Perilaku Oportunistik Penyusun Anggaran (Studi pada Kabupaten/ Kota di Provinsi Jawa Timur). Universitas Jember.

Oktariniatmaja, R. (2011). . Pengaruh Pendapatan Asli Daerah, Dana Alokasi Umum dan Dana Alokasi Khusus terhadap Pengalokasian Anggaran Belanja Modal dalam Anggaran Pendapatan dan Belanja Daerah Pada Pemerintah Daerah Kabupaten/Kota di Pulau Jawa, Bali dan Nusa Tenggara. E-Journal Universitas Sebelas Maret.

Parwati, S. M. (2015). Perilaku Oportunistik Penyusu Anggaran di Kabupaten/Kota Se- Bali. Tesis, 127-133.

PP 71 2010. https://doi.org/10.1016/ j.aquaculture.2007.03.021

Prasojo, E. (2009). Reformasi Kedua-Melanjutkan Estafet Reformasi. Jakarta: Penerbit Salemba Humanika. 
Riharjo, I. B., \& Isnadi. (2010). Perilaku Oportunistik Pejabat Eksekutif Dalam Penyusunan APBD ( Bukti Empiris Atas Penggunaan Penerimaan Sumber Daya Alam ). Ekuitas, 14(3), 388-410.

Ritonga, I. T., \& Alam, M. I. (2010). Apakah Incumbent Memanfaatkan Anggaran Pendapatan Dan Belanja Daerah (APBD) Untuk Mencalonkan Kembali Dalam Pemilihan Umum Kepala Daerah (Pemilukada). In SNA 13 (pp. 1-25).

Sarman, M. (2015). Pilkada Serentak: Quo Vadis Kedaulatan Rakyat (Pertama). Salakan Baru No 1 Sewon Bantul: PT. LKiS Printing Cemerlang.

Schillemans, T., \& Busuioc, M. (2015). Predicting Public Sector Accountability: FromAgency Drift to Forum Drift. Journal of Public Administration Research and Theory, 25(1), 191-215. https://doi.org/10.1093/jopart/muu024

Smith, R. W., \& Bertozzi, M. (1998). Principals And Agents: An Explanatory Model For Public Budgeting. Journal of Public Budgeting, Accounting \& Financial Management Principals, 10(3), 325-353.

Suartini, N. K. A., Ariyanto, D., \& Sari, M. M. R. (2016). Determinan Perilaku Opportunistic Penyusun Anggaran Calon Incumbent Terkait Pilkada Serentak Tahun 2015. Jurnal Ekonomi Dan Bisnis, 1-34.
Sularso, H., Restianto, Y. E., \& Istiqomah, A. E. (2014). Determinan Perilaku Oportunistik Penyusunan Anggaran (Studi pada Kabupaten/ Kota di Jawa Tengah). Jurnal Simposium Nasional Akuntansi 17 Mataram Lombok.

Tanzi, V., \& Davoodi, H. (1998). Corruption, Public Investment, and Growth. The Welfare State, Public Investment and Growth, 1-25.

Undang-Undang Nomor 32 Tahun 2004 tentang Pemerintahan Daerah (Lembaran Negara Republik Indonesia Tahun 2004 Nomor 125, Tambahan Lembaran Negara Republik Indonesia Nomor 4437).

Undang-Undang Nomor 33 Tahun 2004 tentang Perimbangan Keuangan Antara Pemerintah Pusat dan Pemerintahan Daerah (Lembaran Negara Republik Indonesia Tahun 2004 Nomor 126, Tambahan Lembaran Negara Republik Indonesia Nomor 4438)

Undang-Undang Republik Indonesia Nomor 1 Tahun 2015 Penetapan Peraturan Pemerintah Pengganti Undang-Undang Nomor 1 Tahun 2014 Tentang Pemilihan Gubernur, Bupati, Dan Walikota Menjadi Undang-Undang). Indonesia. Von Hagen, J. (2002). Fiscal Institutions and Fiscal Performance. The Economic and Social Review, 33(3), 263-284.https://doi.org/10.1007/ s13398-014-0173-7.2 